\section{Conservative treatment of ventricular tumors secondary to mammary neoplasia in dog: case report}

\author{
Tratamento conservador de tumor de ventrículo secundário à \\ neoplasia mamária em cão: relato de caso
}

\author{
Mário dos Santos Filho'* (D), Daniel Carvalho Hainfellner² (D), Nathália Marques de Oliveira Lemos ${ }^{3}$ (D), \\ Mateus Fernando Senra de Almeida 4 (D) , Diana do Amaral Mendonça4 (D), \\ Marcela Rodrigues Valério de Oliveira Folha ${ }^{4}$ (D), Bruno Ricardo Soares Alberigi da Silva ${ }^{1}$ (D), \\ Julio Israel Fernandes ${ }^{5}$ (D) \& Jonimar Pereira Paiva ${ }^{5+}$ (I) \\ 'Veterinary, MSc, Doctoral Student. Programa de Pós-graduação em Medicina Veterinária, Universidade Federal Rural do Rio de \\ Janeiro - UFRRJ, Seropédica, RJ, Brasil \\ Veterinary, MSc, Autonomous. Rio de Janeiro, RJ, Brasil \\ ${ }^{3}$ Veterinary, Master's Degree Student. Programa de Pós-graduação em Medicina Veterinária, Universidade Federal Rural do Rio \\ de Janeiro - UFRRJ, Seropédica, RJ, Brasil \\ ${ }^{4}$ Veterinary, Autonomous. Rio de Janeiro, RJ, Brasil \\ 5Veterinary, Dsc. Departamento de Medicina Veterinária e Cirurgia, Instituto de Veterinária, Universidade Federal Rural do Rio \\ de Janeiro - UFRRJ, Seropédica, RJ, Brasil \\ ${ }^{\dagger}$ Deceased
}

\begin{abstract}
Cardiac neoplasms are uncommon, but secondary or metastatic neoplasms are relatively frequent, with an incidence 60 times higher than the primary ones. A particularly high frequency of metastatic cardiac involvement has been observed in lung squamous cell carcinomas, urinary tract tumors, and melanomas. However, the incidence is lowbecause of breast tumors in dogs. Cardiac tumors may be symptomatic or, more commonly, an incidental finding observed during the investigation of unrelated problems. The clinical presentation is associated with that of a disseminated neoplasm, and cardiac metastases are generally asymptomatic, but should be considered in patients with a history of neoplasia who present with impaired conduction, breathlessness, cardiomegaly, or arrhythmias. The present report aimed to describe a clinical case of cardiac metastasis of breast neoplasia in a dog in which we focusedon conservative clinical treatment and the importance of investigating the incidental clinical findings.
\end{abstract}

Keywords: endocardial tumor, pericardial effusion, clinical management.

\section{Resumo}

As neoplasias cardíacas são incomuns, contudo as secundárias ou metastáticas são mais frequentes dentre estas, apresentando uma incidência 60 vezes superior às primárias. Uma frequência particularmente elevada de envolvimento cardíaco metastático tem sido observada em carcinoma epidermóide de pulmão, tumores do trato urinário e melanomas. Contudo, existe baixa ocorrência por conta de tumor de mama em cadelas. Os tumores cardíacos podem ser sintomáticos ou, mais comumente, achados incidentais, observados durante investigação de um problema não-relacionado. A apresentação clínica é relacionada à de uma neoplasia disseminada, sendo as metástases cardíacas, via de regra, assintomáticas, contudo devem ser lembradas em pacientes com história de neoplasia, que apresentem distúrbios de condução, sopro, cardiomegalia ou arritmias. O presente relato visa descrever um caso clínico de metástase cardíaca, decorrente de neoplasia mamária em cadela, onde o enfoque é o tratamento clínico conservador, bem como a importância da investigação dos achados clínicos incidentais.

Palavras-chave: tumor em endocárdio, efusão pericárdica, manejo clínico.

\section{Introduction}

Cardiac tumors are neoplasms that originate from the internal lining, musculature, or pericardium of the heart (Mac Gregor et al., 2008). They may be primary or metastatic (Aupperle et al., 2007). The incidence of metastatic tumors of the heart is $1 \%$, with the primary tumors showing higher frequency (Amano et al., 2013). They may affect the epicardium (most common), myocardium, or endocardium (Ware \& Hopper, 1999). \section{B] $\mathbb{M}$ Brazilian Journal of Veterinary Medicine

How to cite: Santos Filho M., Hainfellner D. C. Lemos N. M. O., Almeida M. F. S., Mendonça D. A. Folha M. R. V. O., Silva B. R. S. A., Fernandes J. I., Paiva J.P. (2019). Conservative treatment of ventricular tumors secondary to mammary neoplasia in dog: case report. Brazilian Journal of Veterinary Medicine, 41: https://doi.org/10.29374/2527-2179. bjvm099419

Conflict of interests: No conflict of interests declared concerning the publication.

Received: September 11, 2018.

Accepted: February 20, 2019

Thestudy was carried out at Hospital Veterinário de Pequenos Animais - UFRRJ, Campus Universitário, Seropédica, RJ, Brasil.

\section{*Correspondence}

Mário dos Santos Filho

Instituto de Veterinária, Universidade Federal

Rural do Rio de Janeiro - UFRRJ

Rodovia BR 465, Km 7, Campus Universitário,

Bairro Zona Rural

CEP 23897-000 - Seropédica (RJ), Brasil

E-mail: mariosantoscg@gmail.com 
Pulmonary or mammary carcinomas can reach the pericardium and cause vessel compression, generating pericardial effusions, which can lead to cardiac tamponade (MacGregor et al., 2005). Further, pulmonary neoplasms may grow toward the pulmonary veins, affecting the mitral valve and causing obstructive symptoms (Burke et al., 2007).

Benign tumors are the most common, and both clinical and surgical treatments have favorable results with good life expectancy (Karigyo \& Silva, 2014). However, malignant tumors do not benefit from the current conservative therapies (Hassan \& Smith, 2012). Surgery, chemotherapy, and radiotherapy may prolong the survival of the patients by a few monthsbut are not used as the treatment method (Shapiro, 2001).

The common effects and clinical signsof cardiac tumors are obstructions, embolizations, arrhythmias, and effusions (Burke et al., 2007). 1. Obstructions depend on the size.Atrial tumors may hinder atrioventricular-valve blood flow and mimic valvular stenoses (MacGregor et al., 2005). In ventricular cavities, they can obstruct the exit routes, with signs of dyspnea or syncope (Yeh et al., 2008); 2. Emboli can originate from the tumors or from the adjascent thrombi. Depending on the focus of origin,emboli can be small and multiple, mimicking vasculitis or endocarditis,or large, with occlusive events, such as stroke (Karigyo \& Silva, 2014); 3. Infiltration of the tumor in the myocardium and in the conduction pathways or presence of the tumor mass may cause arrythmias, leading to atrioventricular blocks, ventricular tachycardias, or death (Aupperle et al., 2007); 4. Finally,compression may reduce the oncotic pressure of the vessels and lead to extravasation of the pericardial caviad, causing effusion (Amano et al., 2013). The diagnosis of cardiac neoplasms is based on echocardiographyand computed tomography (Jark et al., 2004; Bussadori, 2015).

Cardiac tumors should be included in the differential diagnosis (Mesquita et al., 2012) of patients with heart murmur, cardiac arrhythmia, and non-specific signs, such as fever and anorexia (Karigyo \& Silva, 2014), especially in those with neoplasia in other regions of the body (Kealy \& Mc Allister, 2005).

Treatment should be surgical resection, with chemotherapy and radiotherapy, and palliative, aimed at systemic care and improving quality of life of terminal patients (Shapiro, 2001).

The present study aimed to describe conservative palliative care, preserving the quality of life of a woman with a ventricular tumor secondary to breast neoplasia.

\section{Historical findings}

For clinical and preoperative evaluation, a 15-year-old teckel with restrictive dyspnea and mammary nodule for two yearswas submitted to the Respiratory Cardiology and Respiratory Diseases Service of the Small Animal Veterinary Hospital. The tutor reported that the bitch had extreme fatigue and loss of appetite.

Physical examination revealed positive cough reflex, hyperkinetic pulses, restrictive respiration, and hepatosplenomegaly. Pulmonary auscultation revealed crepitation all over the chest, while the cardiac sounds were muffled. In addition, restrictive breathing with tachypnea, rectal temperature of $39.8^{\circ} \mathrm{C}$, and capillary perfusion time of $2 \mathrm{~s}$ were observed. The thoracic percussion was hypersonic, with isolated submachine points. The systemic systolic blood pressure was $140 \mathrm{mmHg}$. Radiographic examination of the chest revealed peribronchial and alveolar infiltrates in the caudal lung fields, mainly in the peri-hilar region, with a dorsal displacement of the trachea and main bronchi (Figure 1) and an overall increase in the cardiac silhouette, suggestive of pericardial effusion (Figure 2).

The pericardial effusion was confirmed using T-FAST (Thoracic Focused Assessment with Sonography for Trauma), at which point the presence of cardiac tamponade was detected, and pericardiocentesis was continued (Figure 3). Electrocardiogram monitoring was recommended in this procedureto detect possible findings of needle contact with the myocardium during drainage. Electrical alternation (Figure 4A) and ventricular premature complexes (VPC`s) (Figure 4B) were observed during electrocardiographic recording. After the drainage, $50 \mathrm{~mL}$ of serous-hemorrhagic fluid was obtained, which was sent for cytological examination and analysis for spoliation of possible cancer cells.

Laboratory tests revealed normocytic and hypochromic anemia, elevated alkaline phosphatase and urea, and decrease in phosphorus and ionic calcium. 


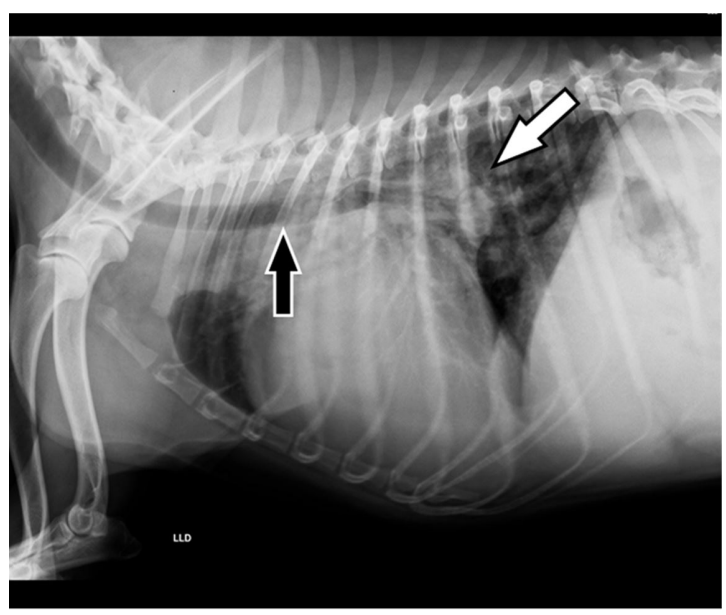

Figure 1. Thoracic radiographic image in the right lateral view showing alveolar pattern in the perihilar region (filled arrow), enlargement of the cardiac silhouette, and dorsal displacement of the trachea (arrow outline). Source: Veterinary Hospital of Small Animals.

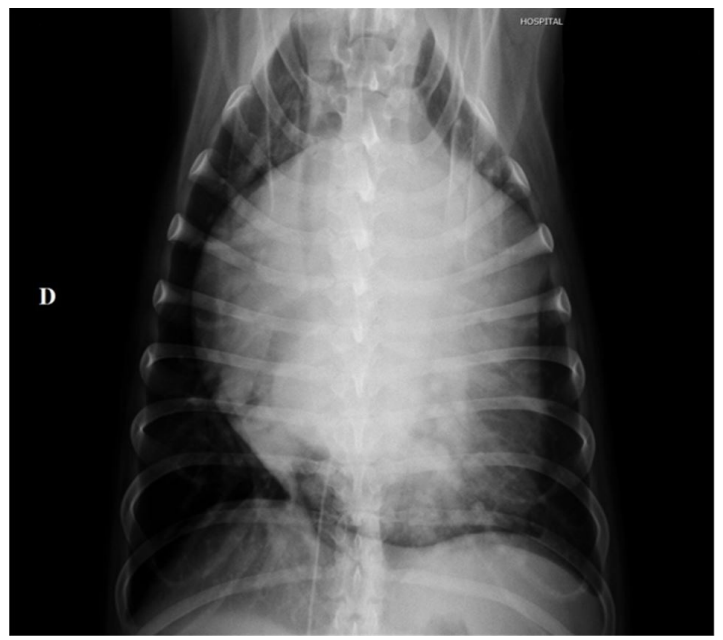

Figure 2. Thoracic radiographic image in the ventro-dorsal view showing an increase in the cardiac silhouette with pericardial effusion.

Source: Veterinary Hospital of Small Animals.

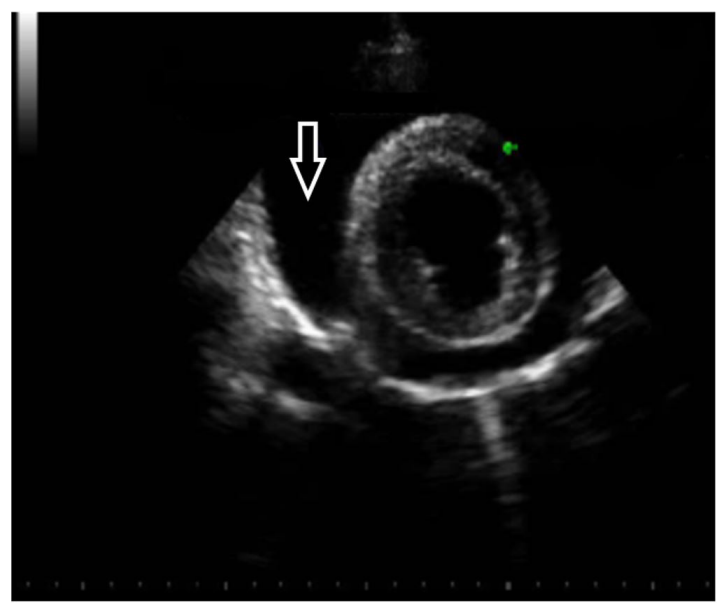

Figure 3. Echocardiographic image in the left ventricular transverse section showing effusion (arrow outline) with cardiac tamponade.

Source: Service of Cardiology and Respiratory Diseases - UFRRJ. 

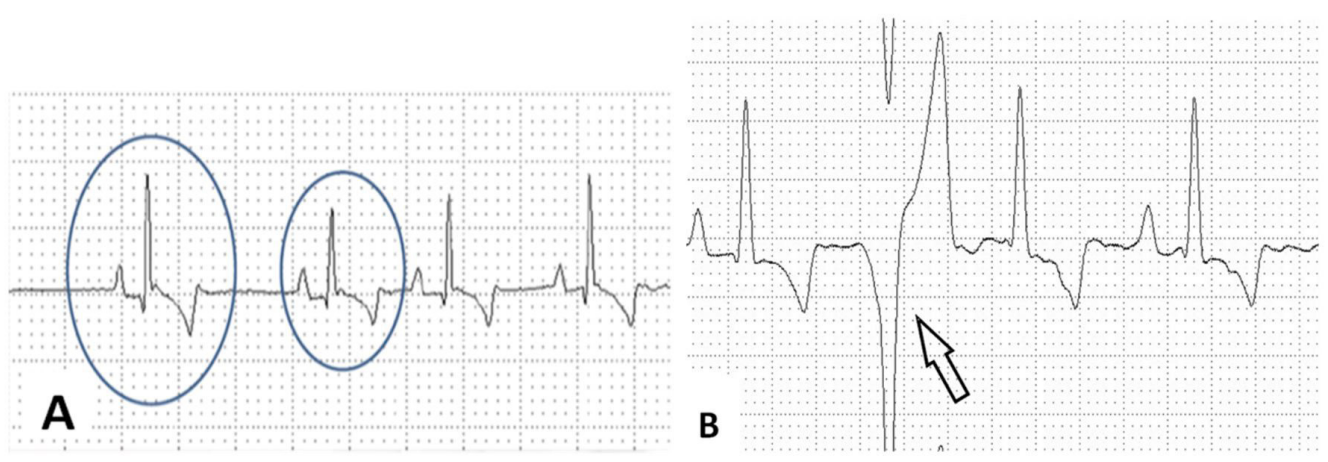

Figure 4. Electrocardiographic tracing revealing: A. Electrical alternation (circles) and B. Premature ventricular complex (arrow outline).

Source: Service of Cardiology and Respiratory Diseases - UFRRJ.

Abdominal ultrasonography showed hepatosplenomegaly, three circumscribed and irregular splenic nodules, with the largest one $(3,74 \mathrm{~cm} \times 2,82 \mathrm{~cm})$ showing vascularization, and inguinal and sublumbar reactive lymph nodes.

Echocardiography showed thickening and insufficiency of the atrioventricular valve leaflets, increase in left atrium size, with an aorta of 1.8. Diffuse involvement of the left ventricular systolic function (shortening fraction: 28\%) was observed, and hyperechoic formation, difficult to measure on the wall, was observed in the transverse section of the left ventricle. Discrete, non-drainable pericardial effusion was also seen.

Enalapril (0,3 mg/kg, BID), pimobendam (0,25 mg/kg, BID), spironolactone (2mg/kg, BID), furosemide (3mg/kg, TID), and omega-3(500mg, SID), were prescribed. At the reassessment after three days, the patient had regained activity and appetite. There was no pericardial effusion, and the breathing was normal. The vital signs were within the normal ranges. A slight crepitation was heard in the peri-hilar region, and the T-FAST examination showed discrete, non-draining effusion (Figure 5).

The only sign of abnormality that required treatment was the presence of polymorphic VPC's on the electrocardiogram, and amiodarone (1mg/kg BID) was added to the therapeutic protocol.

After seven days, the electrocardiogram showed isolated VPC's, without malignancy. Approximately 90 days after the diagnosis, the patient died. At necropsy, breast neoplasia was evident, with metastasis in the lungs, lymph nodes, heart, spleen, and liver. Histopathological examination proved that this was a case of primary adenocarcinoma with metastasis in the cardiac ventricle.

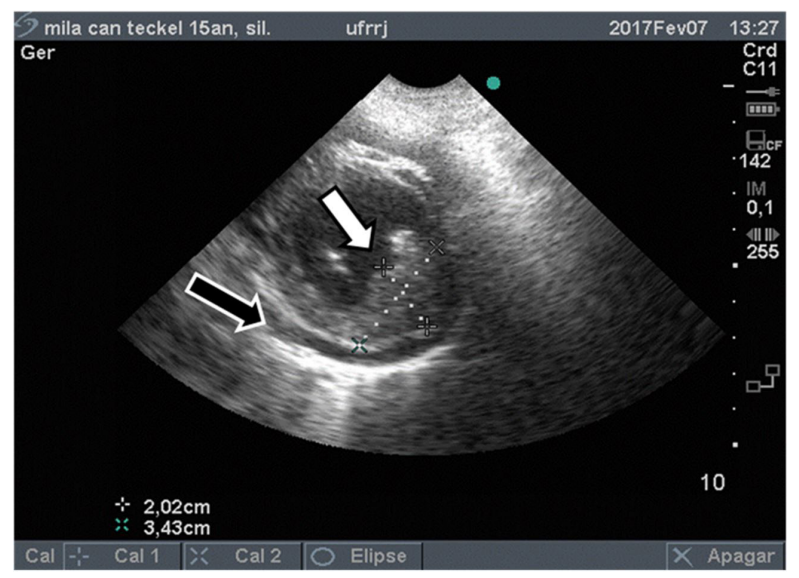

Figure 5. Echocardiographic image in the left ventricle transverse section showing irregularity in the left ventricle wall (filled arrow) and discrete pericardial effusion (arrow outline).

Source: Service of Cardiology and Respiratory Diseases - UFRRJ. 


\section{Discussion}

Effusion originating from the compression of the lymphatic vessels in the mediastinal region appears to justify the occurrence of cardiac tamponade. Although congestive heart disease was present, overtraining of the pulmonary inter-system, and not necessarily of the pericardial space, was expected (Amano et al., 2013).

In the present study, the pericardial fluid was analyzed to detect the cell type: primary or metastatic (Aupperle et al., 2007).

Emergency treatment of pericardial drainage and the establishment of congestive heart failure from vasodilatation by angiotensin-converting enzyme inhibitors (enalapril) reduced pulmonary hypertension and increased the force of cardiac contraction by the inodilator and inhibitor of phosphodiesterase III (pimobendan) with reduced accumulation of pulmonary edema and possible effusions associated with the diuretic action of spironolactone and furosemide (Johnson et al., 2011).

The presence of VPC's was related not only to the compression of the tumor conduction system but also to the release of cytokines in the bloodstream, generating a change in the electrical action potential to generate the impulse, which could be the origin of the paraneoplastic syndrome (Mac Gregor et al., 2008).

The establishment of oncological management minimized the paraneoplastic effects, and thus, reduced spoliation of cancer cells to the other organs, improving the clinical picture, as reported in the literature (Jark et al., 2004).

Although survival after the treatment was not prolonged, it should be noted that the diagnosis was late, which is common in veterinary medicine because of the lack of preventive medicine or limitation of diagnostic resources, such as computed tomography (Kealy \& McAllister, 2005). In the medical practice for small animals, resources for precise diagnosis are necessary for clinical evaluation both in Brazil and other countries (Yeh et al., 2008).

\section{Conclusion}

The use of this clinical report was fundamental to the success and elucidation of this disease, without exposing the patient to the stress of surgery or chemotherapy, with resolution using the palliative treatment for terminal patients, such as supportive medications, drainage of effusions, and oxygen therapy.

\section{REFERENCES}

Amano, J., Nakayama, J., Yoshimura, Y., \& Ikeda, U. (2013). Clinical classification of cardiovascular tumors and tumor-like lesions, and its incidences. General Thoracic and Cardiovascular Surgery, 61(8), 435-447. http:/l dx.doi.org/10.1007/s11748-013-0214-8. PMid:23460447.

Aupperle, H., März, I., Ellenberger, C., Buschatz, S., Reischauer, A., \& Schoon, H. A. (2007). Primary and secondary heart tumours in dogs and cats. Journal of Comparative Pathology, 136(1), 18-26. http://dx.doi.org/10.1016/j. jcpa.2006.10.002. PMid:17270204.

Burke, A., Jeudy Junior, J., \& Virmani, R. (2007). Cardiac tumors. In E.J. Topol (Ed.), Textbook of cardiovascular medicine. (3rd ed., pp. 710-720). Philadelphia: Lippincott Williams \& Wilkins.

Bussadori, C. (2015). Cardiac tumors. In V. Chetboul, C. Bussadori \& E. Madron (Eds.), Clinical echocardiography of the dog and cat (1st ed., pp. 271-282). Philadelphia: Elsevier Health Science. http://dx.doi.org/10.1016/ B978-0-323-31650-7.00018-1.

Hassan, M., \& Smith, J. M. (2012). Robotic assisted excision of a left ventricular myxoma. Interactive Cardiovascular and Thoracic Surgery, 14(1), 113-114. http://dx.doi.org/10.1093/icvts/ivr021. PMid:22108931.

Jark, P. C., Grandi, F., Doiche, D. P., Machado, L. H. A., Lourenço, M. L. G., \& Sequeira, J. L. (2004). Quimiodectoma de corpo aórtico em cão. Clinical Veterinary, 90(1), 54-60.

Johnson, M. S., Martin, M., Binns, S. \& Day, M. J. (2011). A retrospective study of clinical findings, treatment and outcome in 143 dogs with pericardial effusion. The Journal of Small Animal Practice, 45(11), 546-552. http:// dx.doi.org/10.1111/j.1748-5827.2004.tb00202.x. PMid:15553192.

Karigyo, C. J. T., \& Silva, F. B. F. (2014). Tumores cardíacos: uma breve revisão da literatura. Revista do Médico Residente, 16(1), 27-34.

Kealy, K. J., \& McAllister, H. (2005). The thorax. In K. J. Kealy \& H. McAllister (Eds.), Diagnostic radiology and ultrasonography of the dog and cat (4th, pp. 173-295). Missouri: Elsevier. 
Mac Gregor, J. M., Faria, M. L., Moore, A. S., Tobias, A. H., Brown, D. J., Mc Manus, B., \& Lee, C. H. (2008). Primary tumors of the heart. In P. Libb, R. O. Bonow, D. L. Mann \& D. P. Zipes (Eds.), Braunwald's heart disease (8th ed., pp. 1815-1828). Philadelphia: Saunders.

MacGregor, J. M., Faria, M. L., Moore, A. S., Tobias, A. H., Brown, D. J., \& Morais, H. S. (2005). Cardiac lymphoma and pericardial effusion in dogs: 12 cases (1994-2004). Journal of the American Veterinary Medical Association, 227(9), 1449-1453. http://dx.doi.org/10.2460/javma.2005.227.1449. PMid:16279390.

Mesquita, L. P., Abreu, C. C., Nogueira, C. I., Wouters, A. T. B., Wouters, F., Bezerra Junior, P. S., Muzzi, R. A. L., \& Varaschin, M. S. (2012). Prevalência e aspectos anatomopatológicos das neoplasias primárias do coração, de tecidos da base do coração e metastáticas, em cães do sul de minas gerais (1994-2009). Pesquisa Veterinária Brasileira, 32(11), 1155-1163. http://dx.doi.org/10.1590/50100-736X2012001100014.

Shapiro, L. M. (2001). Cardiac tumors: diagnosis and management. Heart, 85(2), 218-222. http://dx.doi.org/10.1136/ heart.85.2.218. PMid:11156679.

Yeh, E. T. H., Lenihan, D. J., \& Ewer, M. S. (2008). The diagnosis and management of cardiovascular disease in cancer patients (section "General manifestations and list of cardiac tumors"). In V. Fuster, R. A. O'Rourke, R. A. Walsh \& P. Poole-Wilson (Eds.), Hurst's the heart (12th ed., pp. 2053-2069). New York: McGraw-Hill.

Ware, W. A., \& Hopper, D. L. (1999). Cardiac tumors in dogs: 1982-1995. Journal of Veterinary Internal Medicine, 13(2), 95-103. http://dx.doi.org/10.1111/j.1939-1676.1999.tb01136.x. PMid:10225598. 